\title{
Non-Financial Incentives and Staff Motivation in Akwa Ibom State Civil Service, Nigeria
}

\author{
Isaac Adeyinka Ayandele \\ Department of Business Management Faculty of Business Administraton University of Uyo, Uyo, Nigeria
}

\section{Etim Osim Etim (Corresponding Author)}

Department of Accounting Faculty of Business Administration Universiity of Uyo, Nigeria

Email: osimacc@gmail.com

\author{
Article History \\ Received: June 15, 2020 \\ Revised: July 21, 2020 \\ Accepted: July 27, 2020 \\ Published: July 30, 2020 \\ Copyright (C) 2020 ARPG \& \\ Author \\ This work is licensed under \\ the Creative Commons \\ Attribution International \\ (क) (1) $\mathrm{CC}$ \\ BY: Creative Commons \\ Attribution License 4.0
}

\begin{abstract}
The study examined the relationship between non-financial incentives and workers' motivation in Akwa Ibom State Civil Service exploring five key variables of continuing professional development, performance feedback, employee employment, employee participation in decision-making and task autonomy. Survey research design was adopted involving the use of questionnaire to gather data from 392 respondents drawn from a population of 20465 civil servants in state using Taro Yamene Sample Size Determination Table. The sample was drawn across all ministries and departments through stratified and convenience sampling techniques. Data collected were analysed using descriptive and inferential statistics. Hypotheses were tested at 0.05 level of significance. The five dimensions of non-financial incentives were positively correlated with workers' motivation from the results of the analysis. Continuing Professional Development $(\mathrm{CPD})$ had the highest correlation value $(\mathrm{r}=0.33, \mathrm{P}<0.01)$. Also, the five null hypotheses were rejected implying that the variables of study influence workers' motivation in Akwa Ibom State Civil Service, Nigeria with beta coefficients and t-values of CPD (0.29;4.313); PF (0.117; 3.500); EE (0.2.141); PDM (0.182; 2.935), and TA $(0.231 ; 2.817)$. It was concluded that since workers' motivation is a vital tool to organizational effectiveness and growth, employers should explore more of non-financial incentives in formulating and implementing employee benefits related policies.
\end{abstract}

Keywords: Non-financial incentives; Workers' motivation; Organizational effectiveness; Growth.

\section{Introduction}

One of the key issues facing contemporary organization whether private or public in developing countries such as Nigeria is how to ensure the workers are highly motivated to achieve organizational goals and objectives. The rationale is most workers in these establishments often have personal goals that are divergent to those of the organization. Given the fact that well motivated workers are essential assets that carry out organizational activities that enhance attainments of set goals and objectives; their motivation is therefore important. Management of organization that want to remain vibrant, competitive and achieve set targets and goals must must therefore understand the relevance of employees benefits that serve as motivation drivers on propellers with a view to aligning policies direction towards that effect.

All organizations require well motivated workers to be successful in their operations, besides other factors. The reason being that well motivated workers are enthusiastic for the success of the organization. The challenge then is how to ensure that workers are well motivated to improve and sustain high performance on the job.

When deployed to motivate workers is the focus of management, one instrument often deployed to motivate workers is incentive. An incentive is any resource or means that seek to persuades, stimulates or drives workers to work harder, improve and sustain high levels of performance on the job. Incentive is subdivided into financial and non-financial. Financial incentives are payments in cash or money form paid to an employee or worker and takes a variety of forms such as wages, salaries, allowances, commissions, bonuses and other cash rewards among others (Chintallou and Mahadeo, 2013).

Non-financial incentive are non-cash benefits or compensation offered to workers in organizations and to motivate them to improve their performance. They are tangible and intangible incentives that employers offer to employees for outstanding performance and or to improve and sustain high performance (Alegbejo, 2013). Nonfinancial incentives used by management to motivate workers include Continuing Professional Development (CPD), Performance Feedback (PF), Employee Empowerment (EE), Participation in Decision Making (PDM) and Task Autonomy (TA) others area recognition, praise, appreciation, advancement on the job, responsibility, merit awards, annual awards, goal setting, challenging jobs and meaningful work, among others (Owolabi and Abdul-Hameed, 
2011). The non-financial incentives are purely intrinsic in nature and may not be satisfied by monetary rewards in the work place (Aborishade and Obioha, 2009).

The study seeks to examine the relationship between the non-financial incentives and workers' motivation in Akwa Ibom State Civil Service, Nigeria.

\subsection{Statement of the Problem}

Over the years, financial incentives have been the main means of motivating civil servants in Nigeria and most empirical studies and theoretical literature seem to focus principally on how employees are motivated by financial incentives. In government, it is believed that people join the civil service basically to earn money, yet despite regular salary increments, there still exist high level of discontentment and demoralization among civil servants in the country, on the premises that financial incentives do not compensate for outstanding performance, achievements, contributions and accomplishments on the job. Consequently, the government in 2010 implemented some nonfinancial incentives in the state civil service in addition to the existing financial incentives to increase workers' motivation and sustain their performance on the job. These non-financial incentives are continuing Professional Development, performance feedback, autonomy. This study is undertaken to examine the relationship between these non-financial incentives and workers' motivation in Akwa Ibom State Civil Service in order to ascertain the extent of correlation among the variables of investigation in the public sector.

\subsection{Hypothesis of the Study}

The following null hypotheses are formulated for the study:

Ho$_{1}$ : There is no significant relationship between continuing professional development and workers' motivation in Akwa Ibom State Civil Service.

$\mathbf{H o}_{2}$ : There is no significant relationship between performance feedback and workers' motivation in Akwa Ibom State Civil Service.

Ho H $_{3}$ There is no significant relationship between employment empowerment and workers' motivation in Akwa Ibom State Civil Service.

$\mathbf{H o}_{4}$ : There is no significant relationship participation in decision-making and workers' motivation in Akwa Ibom State Civil Service.

Hos: There is no significant relationship between task autonomy and workers' motivation in Akwa Ibom State Civil Service.

The essence of this investigation is to shed more light on the effect of non-financial incentives in boosting workers' performance and productivity in the public sector organizations. The rest of the paper is divided into review of related literature, methodology of the study, results and discussion, and conclusion and recommendations.

\section{Review of Related Literature}

In this section, conceptual issues, theoretical framework and review of empirical studies is addressed.

\subsection{Conceptual Issues}

The key concepts and variables of the study are discussed here. These include non-financial incentives, workers' motivation, and civil service.

\subsubsection{Non-Financial Incentives}

In the simplest sense, non-financial incentives are non-cash compensation offered to employees to motivate them for excellent performance (Kreitner and Kinicki, 2007), Non-financial incentives do take the form of tangible and intangible benefits that an employee offers to workers to motivate them to improve and sustain performance on the job (Ijazi and Khan, 2013). They include tangible rewards, social practices and job related factors that are implemented in organizations to motivate employees without direct payment of cash and consists of intrinsic and extrinsic motivators such as achievement on the job, recognitions, plague, responsibility and praise, among others (Armstrong, 2007; Clive, 2004). These benefits are classified as intrinsic because they drive from the word "internal", which comes from inside a person enabling him to try to meet three inherent psychological needs of autonomy, competence and relatedness (Rao, 2011). Extrinsic motivation denotes motivation that comes from outside of a person in return for external compensation not derived from the work itself and may as well take the form of tangible find intangible financial incentives.

In today's workplace, the use of different classes of non-financial incentives to motivate workers and boost their performance on the job is no the increase. The reason adduce is that they are cost effective ad satisfy the deeply held values and intrinsic needs of employees.

Non-financial incentives maybe classified as tangible non-financial incentives, social non-financial incentives and job related non-financial incentive (Narsee, 2012).

\subsubsection{Tangible Non-Financial Incentives}

This refers to tangible items offered $\mathrm{b}$ an organization to motivate employees (Khan et al., 2016). In today's workplace, the use of tangible non-financial incentives to motivate employees and boost performance is on the increase. Gunawan and Febrianto (2014) post that these incentives can take the form of physical items such as desk accessories, coffee mugs, electronic appliances, certificates of honour, wall plagues, customized company pen, 
holder and tray among others. Jeffrey (2003) earlier added that tangible non-financial incentives can take the form of services such as the use of company buses, medical facilities and company machinery for personal projects. Others include free internet access, club privileges and piped-in-music among others.

Jeffrey and Shaffer (2007), pointed out four psychological processes that affect how workers discern physical non-financial incentives in work organizations. The processes are divided into two classes. The first class discerns the value of incentives that involves evaluability and separability, while the second class discerns the value of obtaining incentive that involve justifiability and social reinforcement on the job. They further explained that the expectantly theory of motivation holds that employees would put in more effort on the task that is akin to the worth of obtaining incentives. If the non-financial incentives presented are considered worthwhile by the employees, and meet their expectations and value of obtaining them, then there is high probability that they would be highly motivated to obtain the desire result.

In Sum, Robbins and Judge (2009), concluded that the reason organizations adapt tangible non-financial incentives are because they are performance based, cost effective, easy to administer, provide practical recognition of employee's efforts, and satisfy employees with social and self-esteem needs in organization.

\subsubsection{Social Non-Financial Incentives}

These class of non-financial incentives are concerned with social relationship that exists between superior and subordinates in the workplace. It also related to various festive activities that take place in an organization (Lai, 2009). It also involves the degree of formal and informal appreciations of exceptional performance of employees on the job and the different social activities which workers of an organization organize informally and formally as a way of celebrating achievement or just to let go the stress of work among others (Bandiera et al., 2010; Khan et al., 2016). Social non-financial incentives are also organized in the workplace to reinforce desirable behaviour, work attitude, fostering of employee commitment and recognition for positive actions (Adeyinka et al., 2007). Other forms of social non-financial incentives documented in the literature include "Thank you", "praise", "appreciation" solicitation of advice, ideas and suggestions from employees done formally and informally in the workspace (Falola et al., 2014; Gunawan and Febrianto, 2014; Rahim and David, 2013). These various recognition acts have been found to satisfy employees social and self-esteem needs in organizations and thus boost their motivation in both private and public organizations.

\subsubsection{Job Related Non-Financial Incentives}

These class of non-financial incentives are also called task-related non-financial incentives used by organizations to motivate employees intrinsically (Yavuz, 2004). They denote job factors that lead to intrinsic motivation of employees in the work place (Lai, 2009). They connote employee's strong feelings of self-worth, accomplishment and please in the workplace. Bandiera et al. (2010) argue that these incentive contribute to innate motivation of employees to perform their task because of the contentment they derive from performing their duties.

These jobs related non-financial incentive include job design and redesign, job security responsibility and autonomy, Job enlargement, job enrichment and empowerment. Other are flexible working hours, opportunities for international work trip, employee participation in decision making, continuing professional development, opportunities for promotion and goal setting. These incentives satisfy individual needs which encourage employees to develop the feeling that the work itself worth exerting more effort in it even without high financial incentives (Awad and Odeh, 2011; Dobre, 2013; Khan et al., 2016).

\subsubsection{Concept of Motivation}

Motivation can be explained as the innate derive within an individual that channel the direction and persistence of his spontaneous behaviour (McShane and Von-Glinow, 2000). Robbins and Coulter (2005), view motivation as a series of actions that indicate a person's readiness to put in more efforts to achieve an organizational object, determined by sustaining effort and capacity to achieve some personal needs.

The basic component of the foregoing definition include direction, intensity and persistence. The direction component connotes s persuasive force within an individual to attain a particular object. This implies that when a motivated worker identifies the needs to attain a particular object, they concentrate all efforts to achieve that goal. The intensity component of the definition denoted that amount of effort assigned to the goal. This means that an employee may work harder that other to achieve certain goals. The last component "Persistence" connotes the length of time that an effort is sustained.

This means that a highly persistent worker may not give up until a particular goal is achieve. Besides, motivation cab be considered as willful when the worker decides to Sansone and Harackieweicz (2000), Can Bither be intrinsic or extrinsic motivation. Intrinsic is derived from the word "Internal" which means motivation that comes from inside of a person. Put differently, intrinsic motivation is generated within an individual. An intrinsically motivated worker will try to meet three inherent psychological needs of autonomy, competence and relatedness (Rao, 2011). This implies that a motivated would cherish to have real personal liberty to make decisions, a medium to vent their ingenuity, chances for growth on the job and being recognized for good work and be treated in a courteous and solicitous manner.

Extrinsic motivation denoted motivation that comes from outside of a person in return for external compensation not derived from the work itself. Extrinsic motivation can take the form of tangible financial or non-financial incentives like pay increase, bonuses, allowance, profit sharing, stock options, overtime pay, wall plagues and gift 
certificate among others. For instance, a worker time may exert more efforts to complete a project before the schedule time because of extrinsic rewards that are associated with working effectively.

\subsubsection{Concept of Workers' Motivation}

Workers' motivation can be perceived as an inherent force that derives employees towards attaining specific goals and objectives of an organization (Sani, 2013). It is a reflection of the level of energy, commitment and creativity that workers put in their jobs in the workplace. It can also be explained as the ability to activate and sustain innate potentials of workers' in a desirable direction and intensity to achieve organizational goals and objectives. Employees' motivation denoted the force within individual workers that direct the intensity and persistence of their voluntary behaviours in the workplace to achieve desired results (Mullins, 2005).

The object of employees' motivation in the workplace is to motivate employee to improve their performance so that the organization can achieve its goals and objectives through their performance (Njeri, 2014). It is designed to foster workers' commitment, loyalty, workforce stability and avoid management labour trade dispute (Cheema et al., 2013b; Mamdani and Minhaj, 2016). Other means of achieving workers' motivation includel: treating employees with respect, recognizing employees' achievements, coaching and mentoring of employees' on the job by their immediate superior (Ismajii et al., 2015; Njeri, 2014).

\subsubsection{Concept of Civil Service}

The word "Civil Service" denotes a group of people who are employed to perform the function of government (Nwizu, 2012). Civil Service can also be described as government officials who are employed on professional excellence and whose appointment is permanent and not based on the tenure of office of a political leader (Laximikanth, 2006). Section 227 of the constitution of the Federal Republic of Nigeria (1999), described civil capacity, where employees are charged with the duties of the government. It represents the entire organization of employees of various rank talents and training in the service of government on permanent basis in all government Ministers, Departments and Agencies (MDAs) employed to handle civil affairs in a non-political capacity.

The term civil services do not include military and paramilitary personnel, Judicial officers, political office holders and appointees as well as employees' of specialized statutory corporations or enterprises which run on commercial basis Idemobi et al. (2011).

Section 227 of 1999 constitution of the Federal Republic of Nigeria stipulates the functions of the civil services to include among others the formulation and implementation of government policies and programmes offering expert advice to political heads of ministries or departments and carrying out day to day functions of government in accordance with established rules, regulations and procedures.

The Akwa Ibom State Civil Service is made up of various ministries categorize in a manner consistent with specific activities of government such as education, economic planning and budget, agricultural and natural resources, works, health, commerce and industries, transport, information and culture, youth and sport, among others with the permanent secretaries as the administrative heads and supported with various cadre of officers in each ministry. The state service is managed by the state civil service commission headed by a head of service (Akwa Ibom State Civil Service Handbook, 2018). The structuring is designed to enhance effectiveness and efficiency of operations of government service.

\subsection{Theoretical Review}

This study is anchored on Maslow's hierarchy of needs theory propounded by psychologist Abraham Maslow in 1943 and described people as "wanting beings who constantly want more and what they need hinges on what they already had or possess. According to Gupta (2009) and Rao (2011), Maslow's hierarchy of needs have set of needs to satisfy, (11) human needs are organized in a hierarchical sequence of importance from primary to complex (lll) the system of needs for many human beings is complex with different types of needs influencing the behaviour of a person at a particular time (iv) human beings move from lower level of needs to higher level of needs (v) unsatisfied needs motivate human beings. That is, needs are motivators when they are not unsatisfied. (vi) Needs that are satisfied do not motivate. But when one needs to satisfied, another need emerges to take place, so human being are always struggling to meet some needs at every time (vii) In general, needs of lower level are satisfied before needs of higher level are initiated to motivate behaviour (viii) Higher level needs could be satisfied in many ways than lower level needs in work organizations. This is shown on the figure that follows: 
Figure-2.1. Maslow Hierarchy of needs Theory (1943)

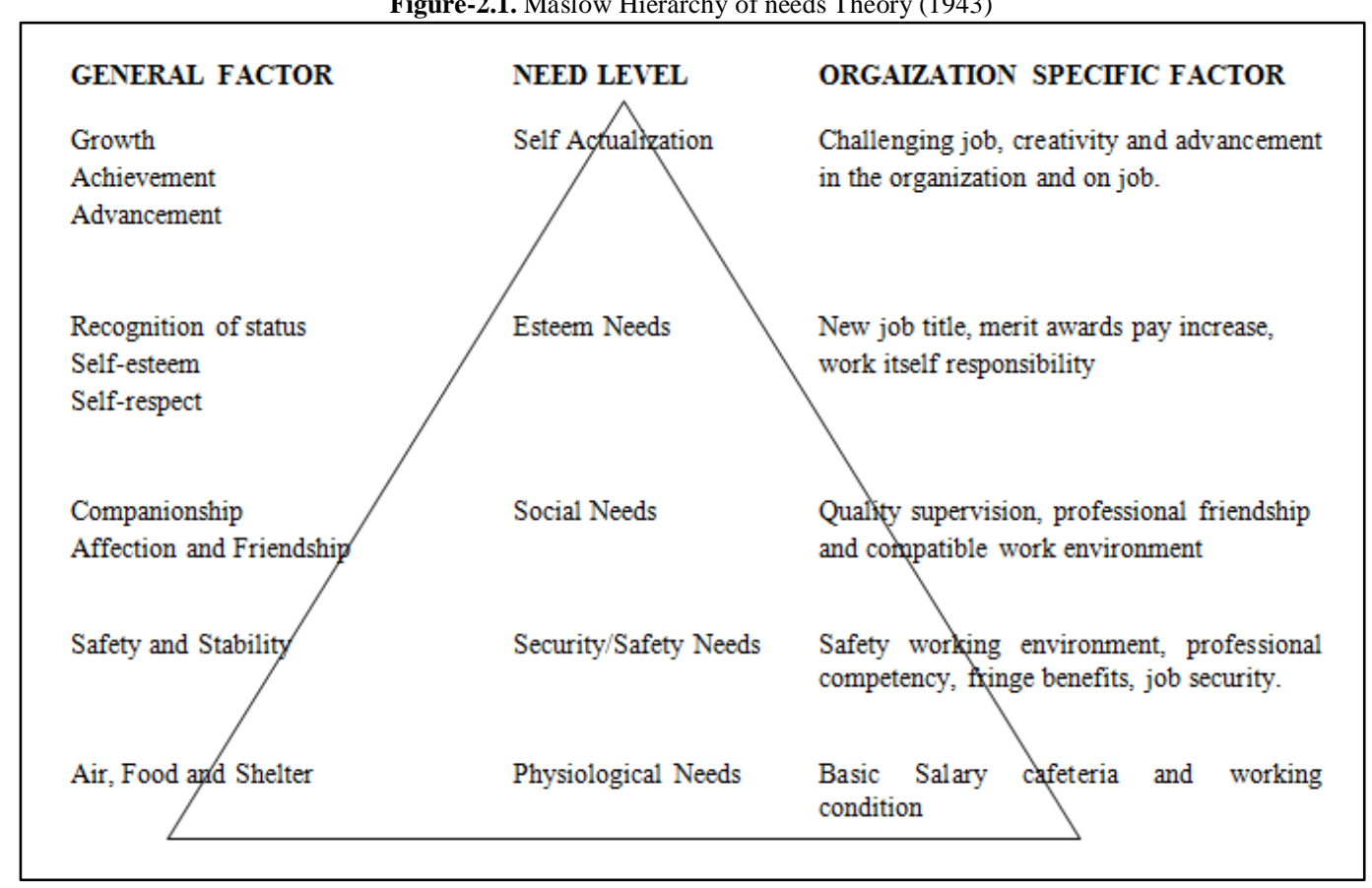

Source: Nnabuife, 1999

Figure 2.1 summarizes the theoretical underpinning for this study.

Maslow (1943), classified human needs into five categories: Physiological needs, safety needs, social needs, esteem needs and self-actualization needs. He called the first three needs deficiency needs or basic or lower level needs. They are characterized as lower level needs, which must be satisfied first for a person to be comfortable and move to next level of needs. While the last two needs are called growth needs or higher order needs which focus on growth and development of an individual.

On key implication of Maslow's theory is that non-financial incentives could be most effective on workers who are satisfying their primary needs but fulfillment of such primary needs in not sufficient to motivate them on the job. Consequently, non-financial incentive plays prominent role in fulfilling other intrinsic needs of workers in the work place which cannot be satisfied by financial incentives.

\subsection{Empirical Studies Review}

Some empirical studies on non-financial incentives and workers' motivation are presented in this section of the paper.

Yavuz (2004), conducted a study on effective utilization of non-monetary incentives as a motivational tool in public organizations in Turkey. The study was corned out using survey research design involving structured questionnaire with a 31 item to gather data from the sample population over a period of nine years. Data collected analyzed using Pearson Product Moment Correlation Analysis, t-test and chi-square statistic. The finishing of the study revealed that employees in the public service cherish non-monetary incentives more than financial incentives and concluded from the findings that non-monetary incentives what however was not clear from the study finding was the extent of the relational between the various of study.

Munga and Mbilinyi (2008), studied the impact of non-financial incentives and motivation of health workers in Tanzania health sector for the period 1980 to 2007. The study involved survey research design using primary data obtained through structure questionnaire. Data gathered were analyzed using chi-square test and product moment correlation coefficient the study result revealed that non-financial incentive are strong motivators for motivating health workers in public health sector if implemented in an effective and sustainable manner. This study also does not disclose the extent of the effect of independent variable on the dependent variable13

Ali and Ahmad (2008), carried out a study on the relationship between non-monetary incentive and employee motivation work organizations using selected so employees of Unilever Nigeria Plc. The research design was exploratory design involving a student questionnaire administer on the sample population to gather data which were analyzed using Pearson Product Moment Correlation Statistic. The result of the study showed a strong positive relationship between non-monetary incentive and employee motivation in the work organization. The research methods adopted only tested relationship and not extent of the cause-effect relationship between variable of study

Axelsson and Bokedal (2009), investigated the impact of non-monetary incentives on motivation of different generation of employees at Volvo Car Corporation over a period six years (2002-2007) Data were collected through personal interviews methods of survey research design on 20 management staff of Volvo Car Corporation at Goteborg plant. Data collected were analyzed using chi-square statistic. Result reveals there exists generational difference between the use of non-monetary incentives and employee's motivation in the corporation under study. The key drawback of the study was the use of only management staff for the study rather than drawing sample across 
board in the corporation since various cadres of employees may have different perception about the variable of study.

Ezigbo and Court (2011), conducted a research on consequence f monetary and non-monetary incentives on workers' performance in manufacturing organizations in Port-Harcourt, Nigeria for over a period of 10 years from 200 to 2009. The study involved 312 respondents draw from 32 registered companies with the manufacturing Associated of Nigeria (MAN) in the state. Data were collected through primary source involving administration of student questionnaire to the respondent s. Data obtained were analyzed using descriptive statistic using frequency distribution and simple percentage. Results show that non-monetary incentives had more significant positive relationship that monetary incentive on employee performance in manufacturing firms. No result statistic tool was employed in their study.

Cheema et al. (2013a), investigated the impact of non-monetary incentive on employee motivation in commercial bank in Karachi, Pakistan Their study involved a survey research design with a student questionnaire and the instrument for data collection from a sample of 550 respondents draw for the study. Descriptive statistics were used to analyze data and chi-square statistic to test the hypotheses of the study. The finding of the study confirmed there is positive significant relationship between the variable of study.

Njanya et al. (2013), carried out a study on the effect of non-monetary incentives on employee performance in Kenya power and lighting company limited covering a 10years period from 2002 to 2011 primary data gathered through structured questionnaire administered to 68 management staff and employed of the company Descriptive and inferential statistic were employed to analyzed data collected. Finding revealed that non-monetary incentive has significant positive effect on employee performance and motivate employees in public corporations

Harunavamwe and Kanengoni (2013), carried at a research to examine the impact of financial and non-financial incentives on motivation of lower level employees in selected retail shop. A survey research design was adopted for the study involving administration of structured questionnaire to a Sample of 50 respondent selected randomly. Both descriptive and inferential statistics were employee to analyzed the data collected. The finding revealed that nonfinancial incentive has moderate significant impact on motivation of lower level employee in retail shop, while financial incentive had no significant impact on motivation of lower level employees in retail shops. The overall result indicates weak positive relationship exist between financial and non-financial incentive and motivation of lower level employees.

Gikuya (2014), conducted a study to establish the perceived relationship between non-financial incentive and employee motivation in marketing organization in Nairobi. The study involved survey research design using a structured questionnaire to collect data which were analyzed using descriptive statistic and Pearson product moment correction to establish the relationship between non-financial incentive and employee motivation in marketing organization. The study found that non-monetary incentive motivation employee to a great extent with a strong position correlation between the variable of study.

Isanuzu (2014), examined the influence of non-monetary incentive on teacher s performance in community primary schools in Kisarawe District, Tanzania for a period of eight years involving a sample of 72 teachers selected using random and purposive sampling techniques both were collected through interviews, structured questionnaire and documentary review and analyze using qualitative and quantitative tools. The findings revealed that positive significant correlation exist between provision of non-monetary incentive and teacher's performance in the rural primary school in Kisarawe District of Tanzania.

Wagas and Saleem (2014), studied the effect of monetary and non-monetary incentive on employee engagement and form performance in Pakistan. A survey research design was adopted for the study involving use of structured questionnaire administration to 250 respondents to gather data used for the analyses. Linear regression technique was used to estimate the effects of both monetary and non-monetary incentives on employee engagement and firm performance. Fining from the study discussed that non-monetary incentives have more significant positive effect on employee engagement and firm performance than monetary incentives. They concluded that both monetary and nonmonetary incentives increase the level of employee engagement which causes high firm performance.

Okwudili (2015), examined the impact of non-monetary incentives on employees' in select public parastatals in Abia State, Nigeria. Survey research design involving random sampling techniques to select the respondents for the study using a structured questionnaire to gather data. Multiple Regression and Pearson correction coefficient statistics were used to analyzed the data. Results show the value of Pearson correction coefficient for non-monetary incentives to be positive with employees' productivity at 5\% level of significance in Public Parastatals. The researcher Proposes the use of non-monetary incentives to motivate employees. The key drawback of the study was the blanked use of non-monetary incentives which has composite variable as if it is a single variable.

Khan et al. (2016), investigated the relationship between non-monetary incentives and employee commitment in business organizations for a 10 years' period (2005-2014) using survey research design involving structured questionnaire to gather primary data used for the study. The Spearman's rho correlation and multiple regression analyses were applied for data treatment. Results from the study show that job related non-monetary incentives relatively play significant role in enhancing employees' commitment in an organization, thus motivating workers to higher productivity.

From the empirical literature reviewed, most of the studies combine both monetary with mix outcome and some others did not attempt to disaggregate the non-monetary incentives to examine the dimension of specific influence effect, of non-monetary incentives on driving employee's motivation. This study isolates five (5) key of nonfinancial incentives to examine their relationship with workers, motivation in Akwa Ibom State civil service. The 
specific dimensions are: continuing professional development, performance feedback, employee empowerment, participation in decision making and task autonomy.

\section{Methodology}

This section is devoted to explaining the various research methods adopted in conducting the study.

\subsection{Research Design}

The study adopted survey research design involving the use of structured questionnaire to gather data from the sampled population drawn from the existing pool of civil servant as at the last day of 2019 as disclosed by the Akwa Ibom State (Akwa Ibom State Civil Service Commission Gazette, 2019).

\subsection{Population and Sample of the Study}

The population of this study comprises all civil servants in Akwa Ibom State as at December, 2019 (civil service commission 2019). This comprises of 10,968 male staff and 9497 female staff covering 20goverment ministries under the umbrella of the Akwa Ibom State civil service commission.

The sample size was determined using (Yamane, 1967) sample size determination table to determine 392 respondents that constituted the sampled population who were purposively and systematically selected and administered with the questionnaire.

\subsection{Research Instrument}

The research instrument is a structured questionnaire designed and validated by the authors and reviewed by experts in test and measurement musing Likert Scale with five-point Scaling from 4 point for strongly agreed to 0 (Zero) point for undecided, while non-financial incentives were measured by five sub-variables (a) continuing professional development (b) performance feedback (c) employee empowerment (d) participation in decision making and (e) task autonomy.

The reliability test coefficient of the research instrument obtained through a pilot test are presented on Table 3.1

Table-3.1. Test - Retest Reliability analyzes of the research variables

\begin{tabular}{|c|c|c|c|c|c|}
\hline Variables & No. of items & Order of test & Means & Std. Dev. & $\mathbf{r}_{\mathrm{xy}}$ \\
\hline Continuing Professional Dev. & 10 & $\begin{array}{l}1^{\text {st }} \\
2^{\text {nd }}\end{array}$ & $\begin{array}{l}5.98 \\
6.32\end{array}$ & $\begin{array}{l}0.97 \\
1.07\end{array}$ & 0.96 \\
\hline Employee Empowerment & 10 & $\begin{array}{l}1^{\text {st }} \\
2^{\text {nd }}\end{array}$ & $\begin{array}{l}8.25 \\
8.88\end{array}$ & $\begin{array}{l}074 \\
0.82\end{array}$ & 0.84 \\
\hline Task Autonomy & 10 & $\begin{array}{l}1^{\text {st }} \\
2^{\text {nd }}\end{array}$ & $\begin{array}{l}7.67 \\
7.98\end{array}$ & $\begin{array}{l}0.58 \\
0.59\end{array}$ & 0.77 \\
\hline Workers' Motivation & 10 & $\begin{array}{l}1^{\text {st }} \\
2^{\text {nd }}\end{array}$ & $\begin{array}{l}7.13 \\
7.28\end{array}$ & $\begin{array}{l}0.711 \\
0.67\end{array}$ & 0.82 \\
\hline
\end{tabular}

Source: Researchers' Computation, 2020 using SPSS.20

The results of the reliability test show reliability coefficient ranging between 0.72 and 0.96 signifying substantially high reliability values that justify the suitability of the instrument for use in the study.

\subsection{Model Specification and Description of Values}

The variables used in this study are expressed in the following economic model which is adopted to test the relationship between the dependent and independent variables:

Where;

$$
Y=f\left(\beta_{0}+\beta_{1} X_{1}+\beta_{2} X_{2}+\beta_{3} X_{3}+\ldots \ldots \ldots \ldots \ldots+\beta_{n} X_{n}+e \ldots \ldots . \text { Model } 3.1\right.
$$

$\mathrm{Y}=$ Dependent Variables

$f=$ Functional Notation

$\beta_{0}=$ Constant

$\beta_{1}-\beta_{n}=$ Coefficient of Independent Variables

$\mathrm{X}_{1}-\mathrm{X}_{\mathrm{n}}=$ independent variables

$\mathrm{e}=$ Statistic error term

for the purpose of this study, our model stated in a linear form is expressed as:

$\mathrm{WM}=\propto+\beta_{1} \mathrm{CPd}+\beta_{2} \mathrm{PF}+\beta_{3} \mathrm{EE}+\beta_{4} \mathrm{PDM}+\beta_{5} \mathrm{TA}+\mathrm{e} \ldots \ldots \ldots \ldots$ model 3.2

Where;

$\mathrm{WM}=$ Workers' Motivation (Dependent variable)

$\mathrm{CPd}=$ Continuing Professional Development (independent variable) +

$\mathrm{PF}=$ Performance Feedback (independent variable) +

$\mathrm{EE}=$ Employee Empowerment (independent variable) + 
PDM = Employee Participation in Decision Making +

TA = Task Autonomy (independent variable) +

$\mathrm{e}=$ Stochastic error term

The model is used to test the five hypotheses of the study

\subsection{Estimation Technique}

Data for the study were analyzed using descriptive and inferential statistics. The relationship between the dependent and independent variables is estimated using Pearson Product Moment Correlation Analysis (PPMC), while the multiple regressions analysis is used to test all hypothesis at 5\% level of significance. A null hypothesis is rejected if the probability value was less than $0.05(\mathrm{P}<0.05)$. That is, if the calculated F-statistic at $5 \%$ level of significance is greater than the tabulated or critical F-statistic, the null hypothesis will be rejected, otherwise accepted.

\section{Results and Discussion}

This section presents the data analysed and the accompanying discussions.

\subsection{Presentation and Analysis of Empirical Results}

The section is carried out in the major steps; presentation of the correlation analysis result, followed by test of hypothesis using the multiple regression analysis.

Table-4.1. Descriptive Statistics for the valuables of study

\begin{tabular}{|c|c|c|c|c|c|c|}
\hline Variable & $\mathbf{E E}$ & PF & CPD & TA & PDM & $\mathbf{W M}$ \\
\hline Employee Empowerment & 1.00 & & & & & \\
\hline Performance Feedback (PF) & $.676^{* *}$ & 1.00 & & & & \\
\hline Continuing Professional Dev (CPD) & .083 & $.178 * *$ & 1.00 & & & \\
\hline Task Autonomy (TA) & $.547 * *$ & $.620 * *$ & .088 & 1.00 & & \\
\hline Participation in Decision Making (PDM) & $268 * *$ & $.674 * *$ & $.495 * *$ & $.254 * *$ & 1.00 & \\
\hline Workers' Motivation (WM) & $.210 * *$ & $.312 * *$ & $.366^{* *}$ & $.212 * *$ & $.338 * *$ & 1.00 \\
\hline
\end{tabular}

Table 4.1 shows the Pearson Product Moment Correlation analysis between the dimensions of non-financial incentives and workers motivation. The above result implies that the relationship between the dependent variables (workers' motivation and independent variables are all positive and significant at 0.01 level of significance. The highest correlation variables are between continuing professional development (CPD) and workers' motivation (WM) $(\mathrm{r}=0.33, \mathrm{P}<0.01)$. However, the more the Civil Service employs the five non-financial incentives the more staff will be motivated, with the highest motivator being continuing professional development.

\subsection{Test of Hypothesis}

In order to test the hypothesis stated for the study, the multiple regression was carried out. This was imperative to estimate the predictive effect of each of the independent variables on the dependent variables. The results are summarized and presented on Table 4.2.

Table-4.2. Multiple Regression Analysis showing effect of Non-Financial Incentives on workers' motivation

\begin{tabular}{|c|c|c|c|c|c|}
\hline Variables & Beta Estimate $\beta$ & Standard Error & T-statistic & Sig. P-value & Remarks \\
\hline $\mathrm{CPD}(\propto)$ & 0.138 & 0.040 & 3.450 & 0.000 & \\
\hline $\mathrm{CPD}$ & $0.239 * *$ & 0.055 & 4.313 & 0.000 & Reject $\mathrm{Ho}_{1}$ \\
\hline $\mathrm{PF}$ & $0.117 * *$ & 0.033 & 3.500 & 0.001 & Reject $\mathrm{Ho}_{2}$ \\
\hline $\mathrm{EE}$ & $0.212 * *$ & 0.099 & 2.141 & 0.001 & Reject $\mathrm{Ho}_{3}$ \\
\hline PDM & $0.182 * *$ & 0.062 & 2.935 & 0.000 & Reject $\mathrm{Ho}_{4}$ \\
\hline TA & $0.231 * *$ & 0.082 & 2.817 & 0.005 & Reject $\mathrm{Ho}_{5}$ \\
\hline \multicolumn{6}{|c|}{$\begin{array}{l}\mathrm{R}^{2} \quad 0.752 \\
\text { Adjusted } \mathrm{R}^{2} 0.632 \\
\text { F-value } 48.666\end{array}$} \\
\hline
\end{tabular}

Table 4.2 shows the regression coefficients estimating the effects of the independent variables on the dependent variable. The $\mathrm{R}^{2}$ value of $0.752(75.2 \%)$ suggest a strong positive relationship between the variables of study. Also, the adjusted $\mathrm{R}^{2}$ of $0.632(63.2 \%)$ explains that variation in workers' motivation in the Civil Service of Akwa Ibom State is accounted for by the 5 non-financial incentives variable of Continuing Professional Development (CPD), Performance Feedback (PF), Employee Empowerment (EE), Participation in decision-making (PDM) and Task Autonomy (TA). 
The result of the model also appears robust with F-value of 48.666, which is significant 0.05 level. The DurbinWatson statistic of 1.834 implies that auto correlation problem was not an issue in the data since the is close to acceptable threshold of 2.00 .

The beta coefficients, t-statistic and P-values for each of the independent variables reveals: continuing professional development $(\mathrm{CPD})(\beta=0.29, \mathrm{t}=4.313 ; \mathrm{P}=000)$, performance feedback $(\mathrm{PF})(\beta=0.117 ; \mathrm{T}=3.500, \mathrm{P}$ $=0.001)$; Employee Empowerment $(\mathrm{EE})(\beta=0.182, \mathrm{t}=2.935, \mathrm{P}=0.000)$ and Task Autonomy $(\mathrm{TA})(\beta=0.2817, \mathrm{P}=$ 0.005). The five null hypothesis were rejected and the alternative were accepted. Continuing Professional Development had the highest beta coefficient of 0.239 predictor of workers' motivation. This implies that a unit increase in continuing professional development through programmes as training, mentoring, seminars conferences, and motivation. These variables tend to increase workers' motivation in terms of productivity, less absenteeism, increase work hours, subordination, less grievances, commitment, reduced labour turnover and less agitation for pay increase.

\section{Discussion of Findings}

From the results of the analysis, it was revealed that non-financial incentives play vital roles in the motivation of workers in the Akwa Ibom State Civil Service. The study revealed that continuing professional development programmes help workers to remain competent, effective and innovative in their job performance. This finding is consistent with the findings of Okafor (2014) and Dobos (2013) who explained that continuing professional development motivates workers to build confidence and trust in their ability to perform their job well, gain more skills, knowledge and abilities to accomplish challenging tasks and take higher responsibilities in the workspace. Performance feedback is a means of providing clear quantitative and qualitative information to workers about their actual performance on the job for purpose of motivating, improving or maintaining performance. The findings were consistent with that of Dobre (2013), Matsui et al. (2003) who noted that performance feedback drives and sustained employees' motivation when given unbiased, correctly in details and regular based on individual or group performance.

Employee empowerment implies providing workers at all levels of an organization with authority and discretion to control and make decisions on their own concerning their jobs and responsibilities. The findings from the study affirm these variables as a motivating factor in workers to drives them toward goal-directed performance. This finding is corroboration by similar findings of Elnaga and Imran (2014), Baumgartner (2014), Demiree and Esbras (2010).

Employee participation in decision-making was also found to be a significant motivator of Akwa Ibom State Civil Servants as the results disclosed. As reported by Noah (2008), Sagie and Ayean (2003), participation in decision making is one key factors that minimizes workplace conflict and stress, organizational peace, commitment and enhance efficiency. This is confirmed by the study findings.

The study findings also confirm the positive relationship between task autonomy and workers' motivation in the Akwa Ibom State Civil Service as it has to do with the freedom to determine one's work schedule, procedure and method of performing assigned tasks and responsibility in the workplace. The findings support the results of Jeung and Yoon (2010) and Gikuya (2014), who provided meta-physical evidence that task autonomy motivate employees intrinsically in work organization.

\section{Conclusion and Recommendation}

In conclusion, the motivation of employees plays one of the most vital roles in an organization's effectiveness and assertively contributes to its growth and prosperities. Therefore, it is necessary for the Akwa Ibom State Government and any other employer to understand what truly motivates the employees and how to maximize the overall job performance. The theoretical framework of the study and the findings had confirmed that non-financial incentives are very vital for workers' motivation. It is pertinent, therefore, that employers consider all the variables studied in this study to formulate and implement policies that has to do with employees benefits in organization.

It is recommended for further studies demographic factors that determine workers' motivation in organization.

\section{References}

Aborishade, R. and Obioha, E. E. (2009). The use of Non-monetary motivation in enhancing job commitment in Nigeria industries: A case study of Energy Foods Company Limited, Ibandan. Journal of Social Science, 19(2): 149-54.

Adeyinka, T., Ageni, C. O. and Popoola, S. O. (2007). Work motivation, job satisfaction and organizational commitment of library personnel in academic and research librances in Oyo State, Nigeria. Library Philosophy and Practice, 3(2): 63-84.

Akwa Ibom State Civil Service Commission Gazette (2019). Government press: Uyo. 212.

Akwa Ibom State Civil Service Handbook (2018). Government press: Uyo. 212.

Alegbejo, T. B. (2013). A study of non-monetary rewards as a motivation tool for employee performance in Tesco. Unpublished M.Sc. Thesis, University of East London, United Kingdom. 186.

Ali, R. and Ahmad, M. S. (2008). The impact of non-monetary incentives on employees' motivation in work organizations. An empirical study. International Review of Business Research Papers, 5(4): 270-379.

Armstrong, M. (2007). Handbook on employee reward management and practice. Kogan Page: London. 520. 
Awad, B. and Odeh, M. (2011). The impact of incentives on naples hosptal employees. Business Administration, Naples, Alnajah National University. 214.

Axelsson, A. and Bokedal, S. (2009). Reward systems motivating different generations. A case study of Volvo car corporation. University of Gottenburg. http://gupea.ub.se/bitstrea/2077/21241/1/gupea_2077_2124_1paf

Bandiera, O., Barankay, I. and Rasil, I. (2010). Social incentive in the workplace. Review of Economic Studies, 77(3): 417-58

Baumgartner, J. (2014). Benefits of employee empowerment for service quality and job satisfaction in the hospital, industry. Unpublished B.Sc project, Modul University, Vienna. 115.

Cheema, F. E., Sobia, S. and Raffia, A. (2013a). Impact of non-monetary rewards on employees' motivation in commercial banks in Karachi. Journal of Management and Social Sciences, 9(2): 23-30.

Cheema, F. E., Shujaat, S. and Alaam, J. (2013b). The effects of monetary incentives on effort and task performance: Theories, Evidence and a Framework for research. Accounting, Organization and Society, 27(5): 303-45.

Chintallou, S. and Mahadeo, J., 2013. "Effect of motivation on employees' work performance at Ireland Blyth Limited." In Procedings of 8th Annual London Business Research Conference, Imperial College, London, $U K$.

Clive, C. N. (2004). Cashless employee motivation baylights compensation consulting. Available: http://www.baylights.com/articles/050zemployeemotivation.himl

Demiree, M. K. and Esbras, A., 2010. "Employee empowerment and its effect on organizational performance." In 2nd International symposium on sustainable development, June 8-9, Sarajevo. p. 310.

Dobos, A. (2013). Experiential learning for professional development in the civil service. Available: www.sciencedirect.com

Dobre, O. J. (2013). Employee motivation and organizational performance. Retrieved of Applied Socio-Economic Research, 5(1): 53-60.

Elnaga, A. A. and Imran, K. (2014). The impact of employee empowerment on job satisfaction. American Journal of Research in Communication, 2(1): 13-26.

Ezigbo, C. A. and Court, O. T. (2011). The effect of monetary and non-monetary rewards on the employees' performance in manufacturing firms in Rivers State, Nigeria. Journal of Sociology, Psychology and Anthropology in Practice, 3(1): 120-29.

Falola, H. O., Ibidunni, A. S. and Olokundun, M. (2014). Incentives packages and employees' attitude to work. A study of selected government parastatals in Ogun State, Nigeria. International Journal Research in Business and Social Science, 3(1): 63-75.

Federal Republic of Nigeria (1999). Constitution of federal republic of Nigeria. Federal Government Printer: Lagos. 128.

Gikuya, C. N. (2014). Perceived relationship between non-monetary rewards and employee motivation at Impact Marketing $(k)$ Limited. unpublished masters Thesis, University of Nairobi, Nairobi.

Gunawan, R. G. and Febrianto, H. (2014). The Impact of Monetary and Non-monetary Incentives on Employees' Motivation in PT Xyz's Finance Function in Surabaya. IBUSS Management, 2(2): 60-79.

Gupta, C. B. (2009). Human resource management New Dehi. Sultanchand and sons educational publishers. 645.

Harunavamwe, M. and Kanengoni, H. (2013). The impact of monetary and non-monetary incentive on montiation among lover levels employees in selected retail shops. African Journal of Business Management, 7(38): 3929-35.

Idemobi, E. I., Onyeizugbe, C. U. and Akpunonu, U. E. (2011). Compensation management as tool for improving organizational performance in the public sectors: A study of the civil service of anambra state of Nigeria. Sacha Journal of Policy and Strategic Studies, 1(1): 109-20.

Ijazi, M. and Khan, A. (2013). The impact of non-financial incentives on employees' motivation. Journal of Business and Management, 15(4): 37-46.

Isanuzu, L. T. (2014). The influence of non-financial incentives on Teachers performance in rural primary schools in Tanzania. Unpublished Master's thesis. Open University of Tanzania. 167.

Ismajii, N., Qosja, E. and Krasnig, I. (2015). The importance of motivation factors on performance in Kosovo municipalities. Journal of Political Science and Public Affairs, 3(2): 1-6.

Jeffrey, S. (2003). Non-monetary rewards: Employees choices and organizational practices. Available: http://www.maritzrewards.com/pdfs/sitebenefits

Jeffrey, S. and Shaffer, V. (2007). The motivational properties of tangible incentives. Compensation and Benefits Reviewed, 2(3): 44-50.

Jeung, C. W. and Yoon, H. J. (2010). Investigating the influences of core-self evaluation, job autonomy, and intrinsic motivation on in-role job performance. Human Resources Dvevlopment Quarterly, 21(4): 353-71.

Khan, M. A., Tarif, A. and Zubair, K. (2016). Non-financial system and organizational commitment: An empirical investigation. Pakistan Business Review, 5(3): 55-75.

Kreitner, R. and Kinicki, A. (2007). Organizational behaviour. McGraw Hill/Iron: Boston. 355.

Lai, C. (2009). Motivating employees through incentives programmes. Unpublished B.Sc thesis, Jyvaskyla University of applied science. http://publicationthesis.f/bitstream/hand1/10024/

Laximikanth, M. (2006). Public administration for the UPSC are service preliminary examination. Tata McGraw publishing company limited: New Delhi. 819.

Mamdani, K. and Minhaj, S. (2016). Effects of motivational incentive of employeees' performance: A case study of banks of Karachi, Pakistan. Journal of Applied Psychology, 8(17): 92-114. 
Maslow, A. H. (1943). A theory oof human motivation. Psychological Review, 50(4): 370-96.

Matsui, T., Okada, A. and Mosluta, O. (2003). Mechanism of feedback affecting task performance. Journal of Applied Psychology, 6(3): 45-52.

McShane, S. L. and Von-Glinow, M. A. (2000). Organizational behaviour. McGraw-Hill: New York. 420.

Mullins, F. K. (2005). Management and organizational behaviour. Pearson Education Limited: England. 592.

Munga, M. A. and Mbilinyi, K. (2008). Non-financial incentives and the retention of health workers in Tanzania. National Institute for Medical Research (NIMR): Daressalam. 214.

Narsee, N. (2012). Comparing the impact of monetary and non-monetary rewards programme toward employee and organization motivation. Available: http://wwwetd.up.ac.za/

Njanya, W. L., Maina, R. N., Kibet, L. K. and Njagi, K. (2013). Effect of rewards on employee performance in Kenya Power and Lighting companyltd., Nakuru, Kenya. International Journal of Business and Management, 8(21): 418-31.

Njeri, D. O. (2014). Employee involvement in decision-making and firm performance in the manufacturing sector in Nigeria. Serbian Journal of management, 6(1): 1-15.

Noah, Y. (2008). A study of worker participation in management decision-making within the selected establishments in Lagos, Nigeria. Journal of Social Science, 17(1): 31-39.

Nwizu, G. (2012). Studies in modern public administration. Whtytem prints: Owerri, Nigeria. 451.

Okafor, L. C. (2014). Motivation and job satisfaction in the Nigeria public service: and research. International Journal of Liberal Arts and Social Science 2(7): 137-47.

Okwudili, B. E. (2015). Effect of non-monetary rewards on productivity of employees among selected government parastatals in Abia State, Nigeria. Journal of Business and Management, 17(2): 6-11.

Owolabi, L. K. and Abdul-Hameed, A. S. (2011). Employee involvement in decision making and firms performance in the manufacturing sector in Nigeria. Serbian Journal of Management, 6(1): 1-15.

Rahim, M. A. and David, W. N. (2013). Rewards and motivation among administrators of University Sultan, Zainal Abidin: An empirical study. International Journal of Business And Society, 14(2): 265-86.

Rao, V. S. P. (2011). Management: Text and cases. Excel Books: New Delhi. 804.

Robbins and Coulter, M. (2005). Management. Pearson Prentice Hall: Upper Saddle River, NJ. 350.

Robbins and Judge, P. (2009). Organizational bahaviour Lodon. Prentice Hall. 600.

Sagie, A. and Ayean, Z. (2003). A cross-cultural analysis of participative decision-making in organizations. Human Relations, 56(4): 453-73.

Sani, M. (2013). An assessment of the impact of non-financial incentives on employee performance: A study of Nigeria Communication Commission (NCC). Unpublished M.Sc Dissertation, Ahmadu Bello University, Zaria, Nigeria. 181.

Sansone, C. and Harackieweicz, J. M. (2000). Intrinsic and extrinsic motivation: the search for optional motivation and performance. San Diego Academic Press. 480.

Wagas, Z. and Saleem, S. (2014). The effect of monetary and non-monetary rewards on employee engagement and firm performance. European Journal of Business and Management, 6(3): 73-82.

Yamane, T. (1967). Statistics: An introductory analysis. 2nd edn: Harper and Row: New York. 512.

Yavuz, N. (2004). The use of non-monetary incentive as a motivational tool: a survey study in a public organization in Turkey. Unpublished M.Sc Dissertation, Middle East Technical University, Turkey. 224. 